\title{
Fiscal reforms and consolidations in Groatia under Excessive Deficit Procedure
}

\author{
ANTO BAJO Institute of Public Finance
}

Due to its high public debt and deficit levels exceeding the thresholds stipulated by the Maastricht criteria, Croatia enters an excessive deficit procedure (EDP). The Government has set up a Commission for fiscal Consolidation but the major concern is that it still has no well-defined agenda for long-term structural reforms aimed at mitigating the existing fiscal risks and ensuring fiscal stability in medium and long-term planning horizons.

\section{THE ACTUAL GOVERNMENT DEFICIT AND DEBT LEVELS}

According to a Eurostat report, the general government deficit and debt, as presented in the EDP Report (in line with the ESA95 methodology) for the period 2009-12, exceed the Government's estimates (produced on the basis of International Monetary Fund's GFS 200I). The sharpest difference between the public debt-to-GDP ratios under the old and the new methodology was observed in 2OII (see Table I). However, quarterly figures on general government deficit and debt are of even greater concern. In the first and second quarters of 2013, budget deficit reached record highs of $10 \%$ and II\% of GDP respectively (Chart I). In the second quarter of 2013, Croatia recorded the second largest budget deficit among the EU member states, after Greece (Chart 2). Given such trend, the country's budget deficit could exceed $6 \%$ of GDP at year-end, and be among relatively high budget deficits in the EU. Due to its general government debt that jumped to 61\% of GDP in July, Croatia ranks among moderately indebted EU member states (Chart 3).

\section{FISGAL DISORIENTATION}

As clearly shown by the Government's Economic and Fiscal Policy Guidelines for the period 2014-16, GDP growth is primarily based on the expected economic recovery of Croatia's major trading partners (mainly EU member states), and, to only a small extent, on domestic reforms aimed at boosting economic growth. The Guidelines indirectly suggest that the Government is not willing to launch or implement any major structural reforms on the expenditure side of the Budget (notably those producing positive effects in the short run), but that it will rather seek guidance on defining the reforms from EU institutions - especially the European Commission (hereinafter: Commission). As a result, Croatia will continue to be exposed to the risk of economic movements in the main trading partners in EU (Austria, Germany, Italy, etc.), while the responsibility for fiscal governance has been "delegated" to the Commission. Consequently, any unpopular measures of structural fiscal adjustments 
will be directly associated with the advice coming from the Commission, rather than with the Government and responsible ministries. Such a "fiscal strategy" could intensify public antagonism towards the European economic integrations, which is very much supported by the government's announced "structural reforms".

\section{(LACK OF) FISGAL CO-ORDINATION}

As a result of undergoing an EDP, Croatia is obliged to propose to the Commission measures aimed at reducing its deficit below $3 \%$ of GDP. Judging by the Government's attitude towards the implementation of structural reforms, it is pretty likely that Croatia will stay long in the EDP (just like Hungary, which exited the procedure after almost nine years). Instead of urgent reforms on both the revenue and expenditure sides, and quantitative assessments of fiscal effects of the reform measures (on the amounts of revenue, expenditure and budget deficit), the Government in October 2013 set up a Co-ordinating Body for the Monitoring and Implementation of Reform and Other Fiscal Consolidation Measures, 2014-16, consisting of the majority of the current Government members. The Body is obliged to co-ordinate and monitor the implementation of reform and other fiscal consolidation measures, to examine the need for additional measures and to co-ordinate the work of operating teams in putting the measures into effect. The operating teams are obliged to set deadlines for carrying out the planned activities and implementing individual measures, and to regularly inform the Co-ordinating Body and its members thereof. Unfortunately, however, instead of a quick improvement in the current institutional framework, the Government has created an inefficient parallel system for making decisions on fiscal consolidations and reforms.

\section{PUBLIC DEBT MANAGEMENT STRATEGY AND BORROWING}

Despite the problems with the level and structure of budget deficit and public debt, Croatia still has neither an up-to-date public debt management strategy nor a public debt law. While most EU member states (especially the new ones) have already developed and updated their public debt management strategies for the period 2014-16, it is incredible, given Croatia's unfavourable fiscal position, that the Government has neither prepared a new Strategy nor published updated reports on the level and structure of public debt, borrowing conditions, annual and even monthly needs for general government borrowing, borrowing calendar, etc. An Act on Public Debt Management is necessary, because the provisions on government borrowing and public debt management are scattered across various pieces of legislation and regulations (e.g. Budget Act, annual budget execution acts, Fiscal Responsibility Act, Mandatory Pension Funds Act, Act on the Croatian National Bank, Capital Market Act, Rules on the Borrowing Procedure for Units of Local and Regional Self-government and Issuing Guarantees, etc.). Against the background of growing budget deficit public debt and contingent liabilities, it is reasonable and necessary to adopt a new Public Debt Management Strategy and introduce a new Public Debt Management Act.

\section{There is A NEED For a Public DebT MANAgement Agency}

In the latest Economic and Fiscal Policy Guidelines, the Government has set as its task the moving of the operations of all agencies to the state budget. This seems to be a good measure, as it ensures the carrying out of the complete operations of major agencies (including their fee revenue collection ) through the central budget, and not (as before) outside the budget, which involved great autonomy in the management and disposal of liquid funds. The problem is that part of the agencies have more employees and significantly less obligations and responsibilities than have budgetary units. On the other hand, some organisational units within the government, which should have a status of agency ${ }^{\mathrm{I}}$, for example, the Public Debt Management Sector of the Ministry of Finance, unfortunately do not have such status. A comparison with the employee expenses in five agencies dealing with traffic, energy industry and

\footnotetext{
${ }^{\text {I }}$ Five agencies operating outside the state budget employ a total of 332 persons (66 on average per agency).
} 
communications clearly shows that their average salaries per employee considerably exceed those of the director and staff members of the Public Debt Management Sector. The Sector has 7 employees who manage a public debt worth HRK 201 bn and government guarantees in the amount of HRK 54 bn (Chart 4). Obviously, the earnings of agency employees, as compared with those of the Public Debt Management Sector employees, are inversely proportional to the size of these institutions and their significance for the government finance system. The government should set up a Public Debt Management Agency, as an independent body closely co-operating with the Ministry of Finance and CNB, with a highly professional staff capable of efficient debt management. This would reduce current and future costs of government borrowing and provide an impetus to the domestic capital market development.

\section{EXPERIENCE WITH THE IMPLEMENTATION OF REFORMS UNDER THE EDP}

As shown by the experience of the Member States undergoing EDP, or of those which recently came out of the procedure (Table 2), on the revenue side of the budget, most of them made corrections of indirect taxes, (VAT and excise duties), abolished tax relief related to direct taxes (personal income and corporate income taxes) and improved the collection of taxes and contributions. The size and volume of fiscal adjustment on the expenditure side of the budget depended on the size of "the mess in public finance", and it ranged from one-off reductions in current and capital expenditures to more detailed measures aimed at reducing part of expenses on public services and the number of their users. Latvia led the way in restrictive measures on the expenditure side, even at the expense of the living standards of its population. However, in mid-2013, the country successfully left EDP and in early 2014 it is about to achieve another goal - the introduction of the euro. Apart from cutting its budget deficit to 1.2\% of GDP in 2012, Latvia also maintained its public debt at an acceptable level of $41 \%$ of GDP.

\section{GROATIA ANNOUNCES "STRUCTURAL REFORMS"}

Most of the reforms planned in the Government's Guidelines for 20I4 relate to the following:

- technical improvements in the system, expected to produce positive effects within six months after the opening of an EDP (making a list of properties, introducing electronic public procurement, new regulations on student living standards, developing a new payment scheme, setting up a centralised healthcare information system, further development of transport infrastructure, inclusion of agencies in the state budget, etc.); and

- further changes in the tax system (raising the reduced VAT rate and a possible increase in excise duties on tobacco and tobacco products, crude oil and refined petroleum products).

One of the major planned sources of reduction in public debt and budget deficit are receipts from the privatization of numerous enterprises (in majority or minority state ownership), which are also regular users of government guarantees and subsidies.

\section{PROBLEMS WITH MEASURES RELYING ON PRIVATISATION REGEIPTS}

The problem is that privatisations (and, consequently, the collection of privatisation receipts) last longer than six months, i.e. the period in which the Commission expects concrete results of the budget deficit-reducing measures. Even if there is a demand for privatisation, there is little likelihood that the period of six months would be long enough to carry out the financial due diligence of companies, conclude purchase and sale contracts and pay proceeds from sale into the state budget. Let it be reminded that the list of companies to be privatized also includes firms that the Government has long tried to sell, yet without success. None of the countries that proposed and implemented measures to correct their excessive deficits have ever mentioned any privatisations or privatisation receipts.

NEWSLETTER 82 | ANTO BAJO | Fiscal reforms and consolidations in Croatia under Excessive... | Institute of Public Finance 3 


\section{LESSONS TO BE LEARNED AND NECESSARY REFORMS IN CROATIA}

The fiscal potential of the proposed deficit-reducing measures on the revenue side of the budget is low and limited by budget expenditures. It is absolutely clear that the Government must resort to unpopular measures on the expenditure side, as have been implemented by other EU member states undergoing EDP (Table 2). This implies that the austerity measures aimed at bringing public finance to a sustainable level might continue for at least two to four years. Nevertheless, some lessons can still be drawn from the experience of the countries that have already gone through reforms under EDP. The bigger the "mess in public finance" the more inclined governments are to make one-off reductions in expenditures or increase tax rates (notably VAT, excise duties on crude oil and refined petroleum products, tobacco and tobacco products). Countries with greater insight into their fiscal structures and more efficient management systems undertake fine tuning (using instruments on both the revenue and the expenditure side), targeted on certain groups of taxpayers (e.g. the Netherlands), or on users of public services (social welfare, healthcare, etc.) and public sector employees. All reform measures require the estimation and quantification of effects in order to determine their contribution to cut down budget deficit and public debt. By producing reliable quantifications and estimates, the Government proves to be prepared to reduce budget deficit and public debt to long-term sustainable levels.

Table I Croatia's government deficit and debt according to IMF GFS and according to EDP (\% of GDP)

\begin{tabular}{|c|c|c|c|c|c|c|c|c|}
\hline & 2009 & 2010 & $20 I I$ & 2012 & 2013* & $2014^{*}$ & $2015^{*}$ & $2016^{*}$ \\
\hline $\begin{array}{l}\text { I. General government debt } \\
\text { (EDP) }\end{array}$ & 36.6 & 44.9 & 51.6 & $55 \cdot 5$ & & & & \\
\hline $\begin{array}{l}\text { 2. General government debt } \\
\text { (IMF GFS) }\end{array}$ & 35.8 & 42.2 & 47.2 & 53.7 & 56.6 & 60.6 & 63.4 & $65 \cdot 3$ \\
\hline 3. Debt - difference (I-2) & 0.8 & 2.7 & 4.4 & I.8 & & & & \\
\hline $\begin{array}{l}\text { a. General government deficit } \\
\text { (EDP) }\end{array}$ & $5 \cdot 3$ & 6.4 & 7.8 & 5.0 & & & & \\
\hline $\begin{array}{l}\text { b. General government deficit } \\
\text { (IMF GFS) }\end{array}$ & 3.I & $4 \cdot 3$ & 4.5 & 3.5 & 3.5 & 5.5 & 5.I & 4.5 \\
\hline 4. Deficit - difference & 2.2 & 2.I & $3 \cdot 3$ & I.5 & & & & \\
\hline
\end{tabular}

$$
\text { (a-b) }
$$

*Planned values and projections.

Sources: Ministry of Finance, RC: Monthly Statistical Reviews and Economic and Fiscal Policy Guidelines; Croatian Bureau of Statistics and Eurostat.

Table 2 Country-specific measures to end EDP (proposed and enacted)

Revenue measures

\begin{tabular}{|c|c|}
\hline I & Increasing excise duties on energy \\
\hline 2 & $\begin{array}{l}\text { Increasing excise duties on cigarettes and other tobacco } \\
\text { products }\end{array}$ \\
\hline 3 & Introducing tax on insurance premiums \\
\hline 4 & $\begin{array}{l}\text { Improving the efficiency of tax and contribution collection; } \\
\text { increasing the effectiveness of tax audit }\end{array}$ \\
\hline 5 & Raising the general VAT rate, intermediate rate or reduced rate \\
\hline 6 & Lifting the reduced VAT rate on hotels and restaurants \\
\hline 7 & $\begin{array}{l}\text { Reducing the highest reduced rate on certain products (food and } \\
\text { pharmaceuticals) }\end{array}$ \\
\hline 8 & Increasing property tax \\
\hline 9 & Withdrawing dividends from public companies' profits \\
\hline IO & Increasing non-tax revenues \\
\hline II & Increasing tolls \\
\hline $\mathrm{I2}$ & Raising pension insurance contributions \\
\hline I3 & Raising social contributions \\
\hline I4 & Introducing or increasing property tax or capital gains tax \\
\hline 15 & $\begin{array}{l}\text { Reducing social contributions for public administration } \\
\text { employees }\end{array}$ \\
\hline 16 & Reducing transfer tax \\
\hline
\end{tabular}

\section{Country(year)}

Bulgaria (20IO-I2), Czech Republic (2009-I3), Latvia (2009-13) Bulgaria (2OIO-I2), Czech Republic (2009-I3), Latvia (2009-I3), Slovenia (2009-15*) Bulgaria (2OIO-I2)

Bulgaria (2OIO-I2), Latvia (2009-I3), Slovakia (2009I3*)

Czech Republic (2009-I3), Latvia (2009-I3), Lithuania (2009-I3), Cyprus (20I2), Spain (2012) Cyprus (20IO)

Cyprus (20IO)

Czech Republic (2009-I3)

Czech Republic (2009-I3), Latvia (2009-I3)

Lithuania (2009-I3), Cyprus (2OII-2OI2), Spain (2012)

Slovenia (2009-15*)

Bulgaria (2OIO-I2)

Czech Republic (2009-I3), Latvia (2009-I3)

Czech Republic (2009-I3), Latvia (2009-I3), Spain (2012)

Cyprus (2010.)

the Netherlands (2OI2) 


\begin{tabular}{|c|c|c|}
\hline 17 & $\begin{array}{l}\text { Increasing the share of central government in shared tax } \\
\text { revenues (while reducing the share of local government) }\end{array}$ & Latvia (2009-I3) \\
\hline I8 & $\begin{array}{l}\text { Introducing a financial transaction tax and amending the bank } \\
\text { total assets tax }\end{array}$ & Slovenia $\left(2009-15^{*}\right)$ \\
\hline \multirow[t]{2}{*}{19} & $\begin{array}{l}\text { Abolishing tax exemptions and allowances in the income tax and } \\
\text { VAT scheme and in the social contributions scheme }\end{array}$ & France (2OIO-I3) \\
\hline & $\begin{array}{c}\text { Expenditure measures } \\
\end{array}$ & $\begin{array}{c}\text { Country (year) } \\
\end{array}$ \\
\hline I & Freezing/reducing public sector wages & $\begin{array}{l}\text { Czech Republic (2009-I3), Latvia (2009-I3), } \\
\text { Lithuania (2009-I3), Slovenia (2009-I5*) Cyprus } \\
\text { (20IO), France (20IO-I3) }\end{array}$ \\
\hline 2 & Freezing/reducing subsidies and social transfers & $\begin{array}{l}\text { Bulgaria (2OIO-I2), Spain (2OI2), Czech Republic } \\
(2009-13) \text {, Slovenia }\left(2009-15^{*}\right)\end{array}$ \\
\hline 3 & $\begin{array}{l}\text { Reducing the maximum period of receiving unemployment } \\
\text { compensation }\end{array}$ & the Netherlands $\left(2014^{*}\right)$ \\
\hline 4 & Reducing capital investment at the cost of government budget & $\begin{array}{l}\text { Bulgaria (2OIO-I2), Slovakia (2OO9-I3*), Slovenia } \\
\left(2009-15^{*}\right) \text {, Malta }\left(2012^{*}\right) \text {, Portugal (2OI2-I4) }\end{array}$ \\
\hline 5 & Suspending indexation of/freeze pensions & $\begin{array}{l}\text { Bulgaria (2OIO-I2), Czech Republic (2009-I3), Latvia } \\
\text { (2OO9-I3), Slovenia (2O09-15*), France (2OIO-I3) }\end{array}$ \\
\hline 6 & Improving the efficiency and curbing public sector employment & $\begin{array}{l}\text { Bulgaria (2OIO-I2), Malta (2OI2) Cyprus (2OIO), } \\
\text { Spain (2OI2), Portugal (2OI2-I4), }\end{array}$ \\
\hline 7 & Implementing targeted public spending cuts & $\begin{array}{l}\text { Bulgaria (2OIO-I2), Latvia (2OO9-I3), Slovakia (2009- } \\
\left.\mathrm{I}^{*}\right)\end{array}$ \\
\hline 8 & $\begin{array}{l}\text { Improving public debt management (by cutting the cost of } \\
\text { interest) }\end{array}$ & Latvia (2009-I3) \\
\hline 9 & Reducing subsidies and aid & Latvia (2009-I3) \\
\hline IO & Reducing wages in local government units & Latvia (2009-I3) \\
\hline II & $\begin{array}{l}\text { Reducing pensions and imposing restrictions on early } \\
\text { retirement }\end{array}$ & Latvia (2009-I3), Spain \\
\hline 12 & Reducing child, maternity and sickness benefits & Latvia (2009-I3), Lithuania (2009-I3) \\
\hline $\mathrm{I3}$ & Reducing the number of disability pension beneficiaries & Latvia (2009-I3) \\
\hline $\mathrm{I} 4$ & Gradually increasing the statutory retirement age & Lithuania (2009-I3) \\
\hline I5 & $\begin{array}{l}\text { Lifting salary bonuses and suspending promotions of public } \\
\text { sector employees }\end{array}$ & Slovenia (2009-15*), Portugal (2012-14) \\
\hline I6 & Raising the minimum wage level & Bulgaria (2OIO-I2), Latvia (2009-I3) \\
\hline I7 & $\begin{array}{l}\text { Consolidating or abolishing the state agencies or including them } \\
\text { in the state budget }\end{array}$ & Latvia (2009-13) \\
\hline I8 & Reducing local government funding by the central government & Latvia (2009-I3) \\
\hline 19 & Recapitalisation of a state-owned air company & Malta (2OI2) \\
\hline
\end{tabular}

Note: *The country is still undergoing an EDP.

Chart I General government budget deficits in Croatia, from 2012QI to 2013Q2 (\% of GDP)

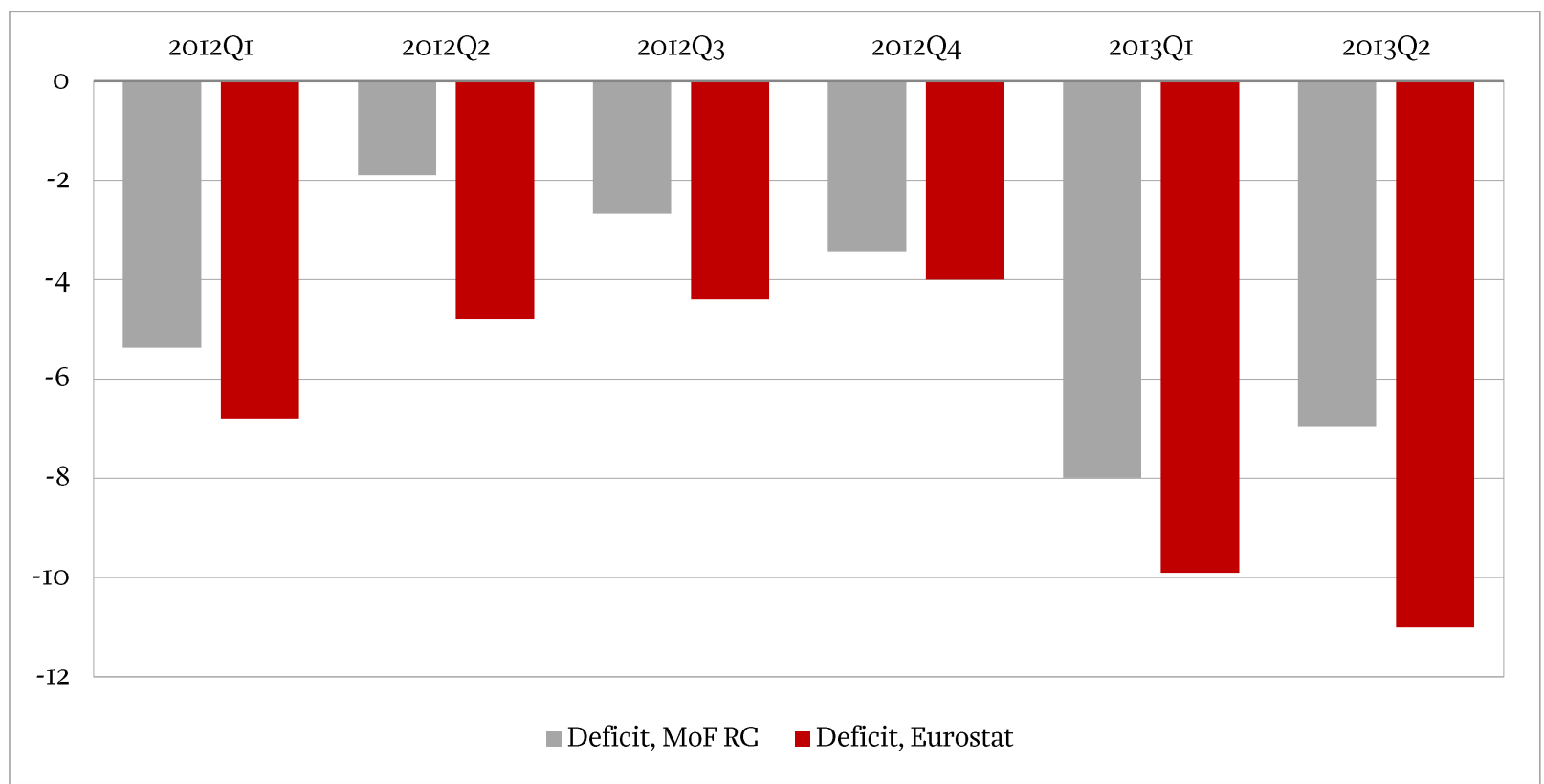

Sources: Eurostat; author's calculation based on data provided by the MoF of the RC and CBS.

NEWSLETTER 82 | ANTO BAJO | Fiscal reforms and consolidations in Croatia under Excessive... I Institute of Public Finance 5 
Chart 2 Budget deficits in Croatia and EU 28, 2013Q1 and Q2 (\% of GDP)

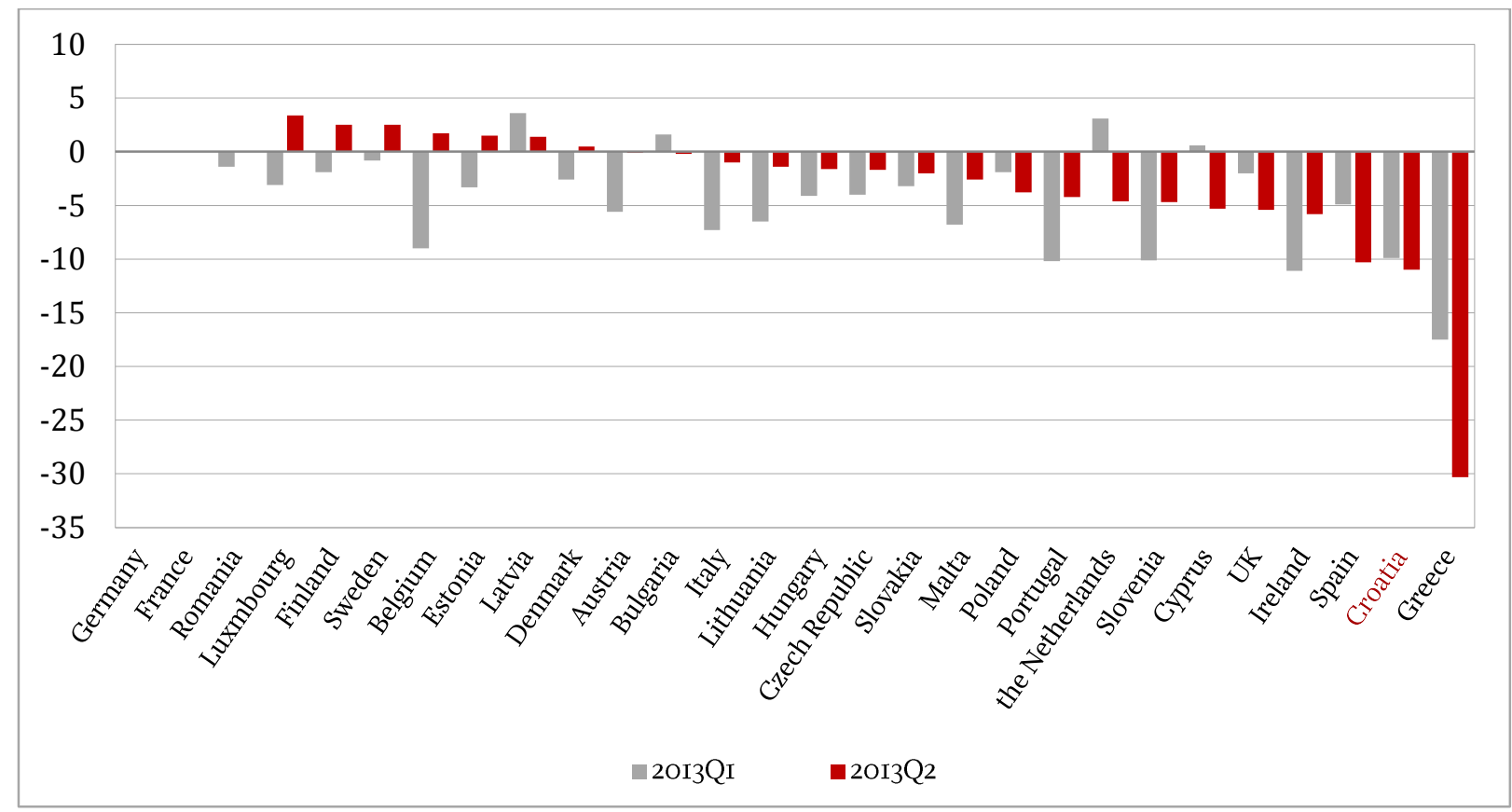

Chart 3 General government debt in EU member states, 2013QI and Q2 (\% of GDP)

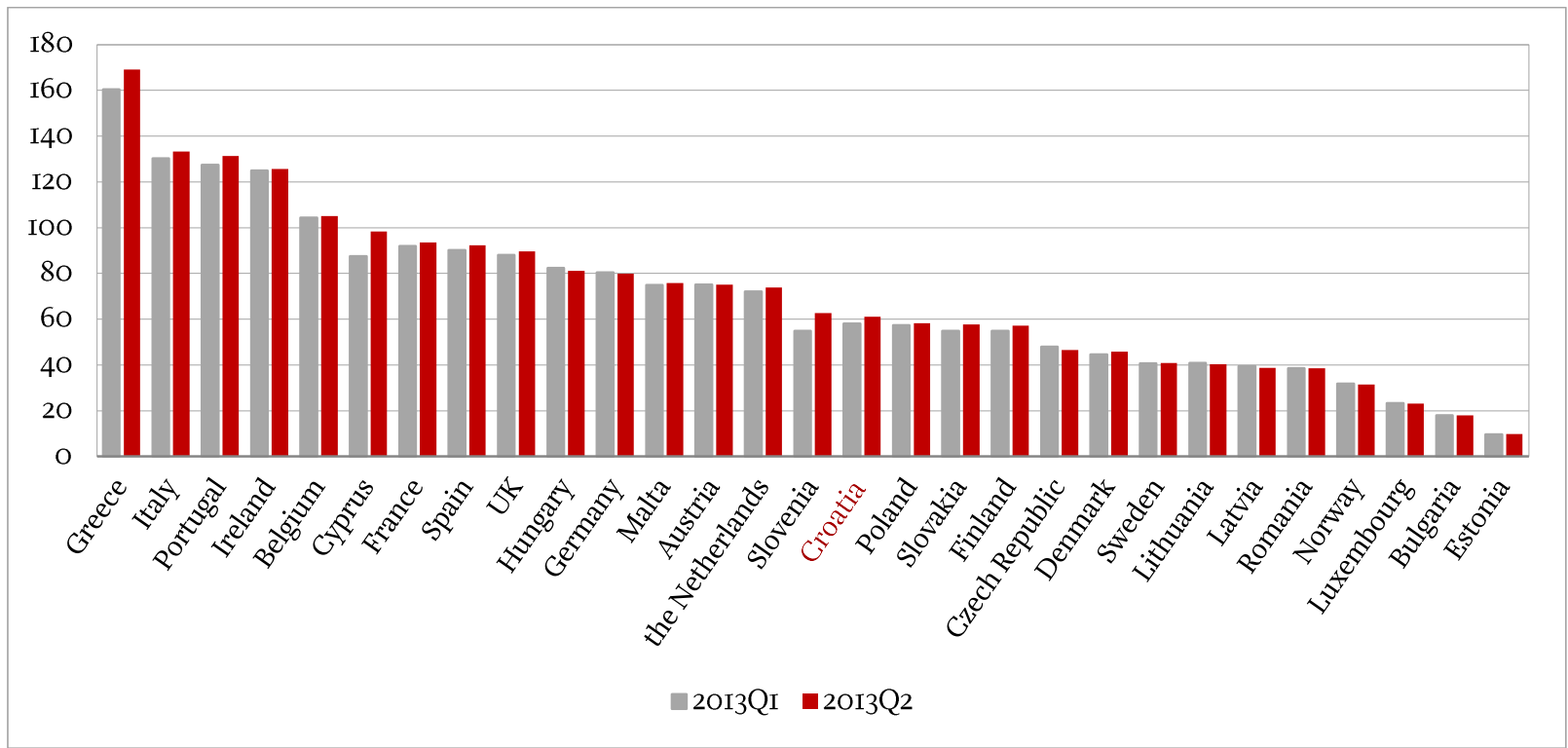

Source: Eurostat; Croatia - author's calculation based CNB and CBS data. 
Chart 4 General government debt and outstanding guarantees in Croatia, 2000-2013

(in billion HRK and as \% of GDP)

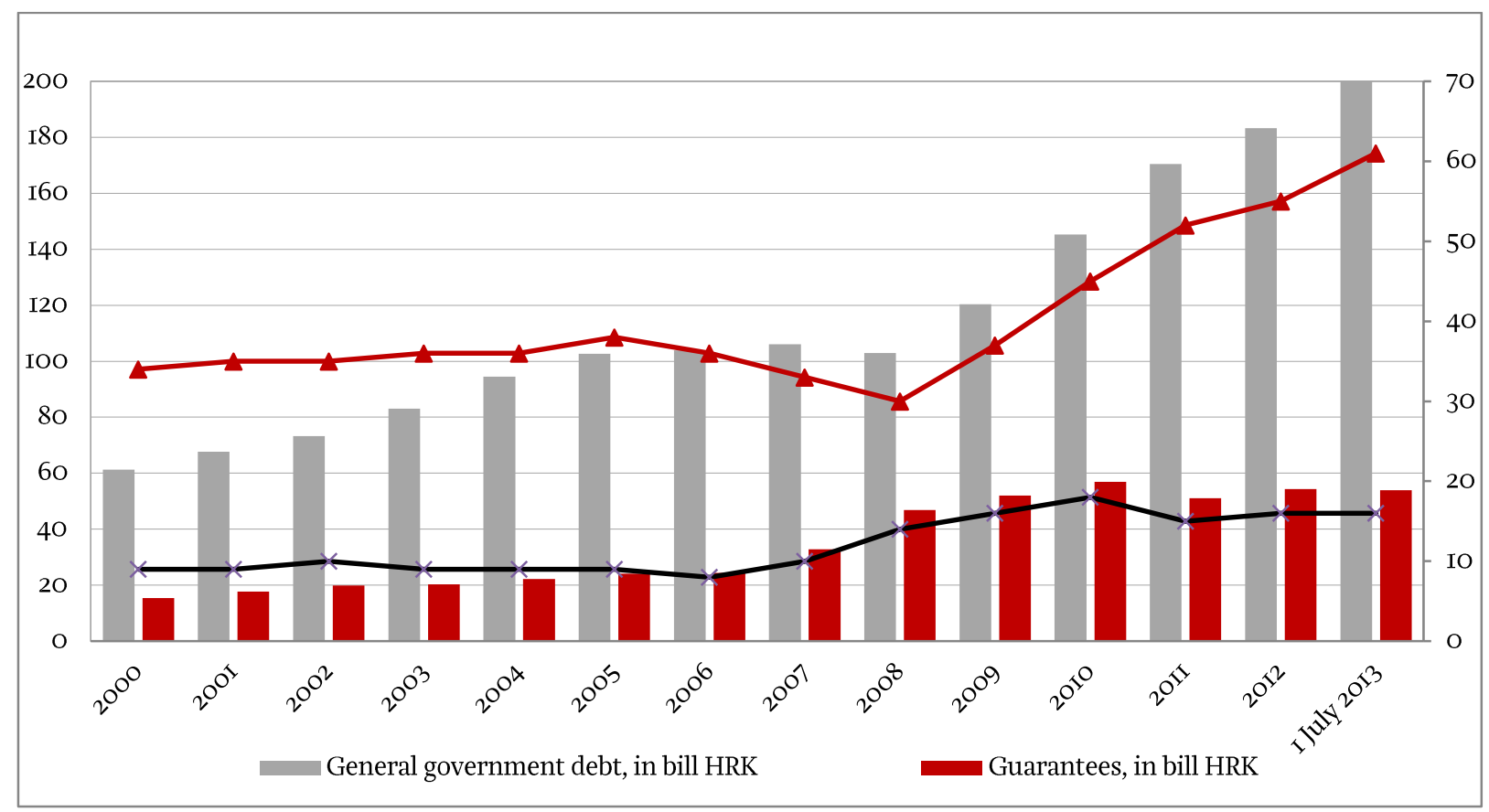

Source: Author's calculation based on CNB and CBS data, 2013.

\section{REFERENCES}

AEM, 2013. Izvješće Hrvatskom Saboru o radu Vijeća za elektroničke medije i Agencije za elektroničke medije u razdoblju od I. siječnja do 3I. prosinca 20I2. Zagreb: Agencija za elektroničke medije.

APEK, 20I3. Letno poročilo APEK 20I2. Ljubljana: Agencija za pošto in elektronske komunikacije Republike Slovenije.

CGAA, 20I3. Financijsko izvješće za 20I2. Zagreb: Hrvatska agencija za civilno zrakoplovstvo.

Eurostat, 2013. Excessive deficit procedures.

HAKOM, 2013. Godišnje izvješće o radu Hrvatske agencije za poštu i elektroničke komunikacije za 2012. Zagreb: Hrvatska agencija za poštu i elektroničke komunikacije.

HANDA, 2013. Financijsko izvješće za 20I2. Zagreb: Hrvatska agencija za obvezne zalihe nafte i naftnih derivata.

HERA, 20I3. Izvješće o radu Hrvatske energetske regulatorne agencije za 2012. Zagreb: Hrvatska energetska regulatorna agencija.

DZS, 2013. Procjena tromjesečnog obračuna bruto domaćeg proizvoda za drugo tromjesečje 2013.

Priopćenje broj I2.I.I/2.

DZS, 20I3. Izvješće o prekomjernome proračunskome manjku i razini duga opće države u Republici Hrvatskoj. Priopćenje broj 12.I.5.

HNB, 2013. Statistički pregled (dug opće države). Zagreb: Hrvatska narodna banka.

Ministarstvo financija, 20I3. Vremenske serije podataka - konsolidirana opća država, siječanj-lipanj 2013. Zagreb: Ministarstvo financija RH.

Vlada RH, 20Io. Popis tijela javne vlasti. Zagreb: Vlada RH.

Vlada RH, 20I3a. Smjernice ekonomske i fiskalne politike za razdoblje 20I4-20I6. Zagreb: Vlada RH.

Vlada RH, 2013b. Odluka o osnivanju Radne skupine za koordinaciju i praćenje provedbe reformskih $i$ drugih mjera fiskalne konsolidacije za razdoblje 20I4.-20I6. Zagreb: Vlada $\mathrm{RH}$ 